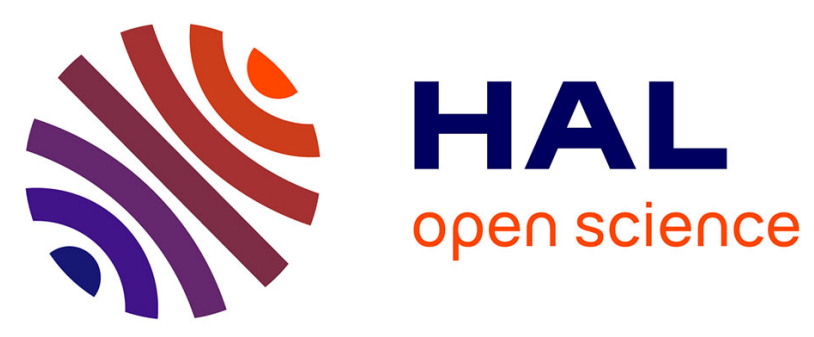

\title{
Barium nitrate Raman laser
}

\author{
P. Zverev, T. Basiev
}

\section{To cite this version:}

P. Zverev, T. Basiev. Barium nitrate Raman laser. Journal de Physique IV Proceedings, 1994, 04 (C4), pp.C4-599-C4-599. 10.1051/jp4:19944150 . jpa-00252606

\section{HAL Id: jpa-00252606 https://hal.science/jpa-00252606}

Submitted on 1 Jan 1994

HAL is a multi-disciplinary open access archive for the deposit and dissemination of scientific research documents, whether they are published or not. The documents may come from teaching and research institutions in France or abroad, or from public or private research centers.
L'archive ouverte pluridisciplinaire HAL, est destinée au dépôt et à la diffusion de documents scientifiques de niveau recherche, publiés ou non, émanant des établissements d'enseignement et de recherche français ou étrangers, des laboratoires publics ou privés. 


\title{
Barium nitrate Raman laser
}

\author{
P.G. ZVEREV and T.T. BASIEV
}

General Physics Institute, Russian Academy of Sciences, Vavilov Str. 38, Moscow 117942, Russia

The use of solid state Raman materials for Stimulated Raman Scattering (SRS) can result in high gain, reliable, small dimension devices for shifting laser output frequencies. $\mathrm{Ba}(\mathrm{NO} 3) 2$ crystal have been identified that possess narrow, isolated intensive Raman active vibronic mode with the energy $1047 \mathrm{~cm}^{-1}$.

Previously we have shown that it is possible to use $\mathrm{Ba}\left(\mathrm{NO}_{3}\right) 2$ crystals 4 - $8 \mathrm{~cm}$ long to shift tunable radiation of nanosecond tunable LiF:F2 ${ }^{-}$color center laser to the first and second Stokes components with efficiency more than $50 \%$ and $25 \%$, respectively [1]. In this case nonlinear crystal is placed outside laser cavity and it is necessary to focus pump laser radiation in the crystal. Focusing lens must be chosen with respect to the parameters of the pump laser beam.

In this report we present results on intracavity SRS of a Q-switched YAG:Nd laser in $\mathrm{Ba}\left(\mathrm{NO}_{3}\right) 2$. An intracavity configuration increases the pump intensity inside Raman media, resulting in high conversion efficiencies and large pulse compression factors. Another important feature of intracavity SRS is that the shifted radiation oscillates as one of the modes of the cavity, resulting in the reduced output divergency of Raman laser.

We used two types of laser cavity including either electro optic Q-switch or LiF:F2 ${ }^{-}$saturable absorber. In both cases we obtained efficient generation at the first and second Stokes wavelengths. The output energy was about $5 \mathrm{~mJ}$ with electric pump energy to the lamp $20 \mathrm{~J}$. The output pulse duration was reduced from 12-15 $\mathrm{ns}$ for $1.06 \mu \mathrm{m}$ to $4-6 \mathrm{~ns}$ for the Stokes components. The divergency of the SRS laser output beam was measured to be $6 \mathrm{mRad}$ which is 10 times smaller than was obtained for single pass SRS in $\mathrm{Ba}\left(\mathrm{NO}_{3}\right)_{2}$ [2].

We have demonstrated that $\mathrm{Ba}(\mathrm{NO} 3)_{2}$ crystals can be used to develop an efficient Raman shifter. Intracavity SRS configuration can result in efficient compact Raman lasers with reduced divergency and pulse duration.

1. T.T.Basiev et al. Sov. J. Quantum Electron. 17 (1987) 1560.

2. P.G.Zverev et al. Opt. Comm. 97 (1993) 59. 